\title{
Kemampuan Strategic Competence Siswa SMP dalam Menyelesaikan Tipe Soal Matematika Higher Order Thinking Skills
}

\author{
Melliana Christie Nugroho', Tri Nova Hasti Yunianta ${ }^{2}$ \\ ${ }^{1,2}$ Program Studi Pendidikan Matematika, Fakultas Keguruan dan Ilmu Pendidikan, Universitas Kristen Satya Wacana \\ Jl. Diponegoro No. 52-60 Salatiga, Indonesia \\ mellianachristie25@gmail.com
}

\begin{abstract}
Strategic competence is the ability to formulate, present, and solve mathematical problems using the correct solution or strategy. Knowing more about the strategic competence of junior high school students is the aim of this research. This research is a descriptive qualitative research in the form of a written test to achieve the goal. The research subjects were taken as many as 3 of 12 students of class VIII SMP Negeri 3 Salatiga. The research subject has studied and knows how to solve the problem of a two-variable linear equation system. Taking the subject seen from the results of working on the questions taken by students with high, medium, and low abilities. Strategic competence tests and interviews on the material of a two-variable linear equation system are tools to collect data. The results of these tests and interviews were analyzed based on three indicators, namely the ability to formulate problems, present problems and solve mathematical problems. The results of the study prove that the strategic competence of students with high abilities have been able to meet all indicators, for students with moderate abilities only meet two indicators, while for students with low thinking skills they have not been able to meet the existing indicators.
\end{abstract}

Keywords: Strategic Competence, Higher Order Thinking Skills (HOTS), Mathematics

\begin{abstract}
Abstrak
Strategic competence merupakan kemampuan merumuskan, menyajikan, dan menyelesaikan masalah matematika dengan menggunakan solusi atau stretegi yang benar. Mengetahui lebih dalam kemampuan strategic competence siswa SMP merupakan tujuan dari penelitian ini. Penelitian ini merupakan penelitian kualitatif deskriptif dengan bentuk tes tertulis untuk mencapai tujuan. Subjek penelitian diambil sebanyak 3 dari 12 siswa kelas VIII SMP Negeri 3 Salatiga. Subjek penelitian sudah mempelajari dan mengetahui cara penyelesaian soal sistem persamaan linear dua variabel. Pengambilan subjek dilihat dari hasil pengerjaan soal diambil siswa dengan kemampuan tinggi, sedang, dan rendah. Tes strategic competence dan wawancara pada materi sistem persamaan linear dua variabel merupakan alat untuk mengumpulkan data. Hasil tes tersebut dan wawancara dianalisis berdasarkan tiga indikator yaitu kemampuan merumuskan masalah, menyajikan masalah dan menyelesaikan masalah matematika. Hasil penelitian membuktikan bahwa kemampuan strategic competence pada siswa dengan kemampuan tinggi sudah mampu memenuhi semua indikator, untuk siswa dengan kemampuan sedang hanya memenuhi dua indikator saja, sedangkan untuk siswa dengan kemampuan berpikir rendah belum bisa memenuhi indikator yang ada.
\end{abstract}

Kata kunci: Strategic Competence, Higher Order Thinking Skills (HOTS), Matematika

Copyright (c) 2021 Melliana Christie Nugroho, Tri Nova Hasti Yunianta

$\triangle$ Corresponding author: Melliana Christie Nugroho

Email Address: mellianachristie25@gmail.com (Jl. Diponegoro 52-60 Salatiga, Jawa Tengah Indonesia)

Received 20 May 2021, Accepted 24 July 2021, Published 08 August 2021

\section{PENDAHULUAN}

Mata pelajaran matematika salah satunya memiliki tujuan supaya siswa memiliki sikap menghargai kegunaan matematika dalam kehidupan, yaitu memiliki rasa ingin tahu, perhatian, dan minat dalam mempelajari matematika, serta sikap ulet dan percaya diri dalam pemecahan masalah (Darmawan et al., 2018). Sariningsih \& Purwasih, (2017) menyatakan bahwa pendidikan matematika dapat mendorong masyarakat untuk selalu maju, terbukti dengan adanya perkembangan teknologi modern. Matematika merupakan salah satu ilmu dasar dalam pendidikan. Matematika diajarkan pada tiap jenjang pendidikan mulai dari taman kanak-kanak, sekolah dasar, sampai sekolah menengah atas ataupun sekolah menengah 
Kemampuan Strategic Competence Siswa SMP dalam Menyelesaikan Tipe Soal Matematika Higher Order Thinking Skills,

kejurusan, bahkan di perguruan tinggi (Yulianti et al., 2017). Afrilianto, (2012) menyatakan bahwa dengan menekuni matematika, siswa sanggup memanfaatkan ide-idenya secara logis, analitis, sistematis, kritis dan kreatif, serta dapat menanggulangi bermacam permasalahan secara bersama-sama dan menggunakan informasi yang diterimanya. Secara umum tujuan penyelenggaraan matematika di sekolah yakni untuk mempersiapkan siswa dalam mengalami keadaan kehidupan yang berganti serta dunia yang terus berkembang (Angraini, 2018).

National Research Council, (2001) menyatakan bahwa Mathematical Proficiency atau keterampilan matematika dapat dijelaskan sebagai aspek ataupun komponen, yang menggambarkan pengetahuan yang harus dipahami siswa supaya sukses belajar matematika. Kilpatrick et al., (2001) menyatakan bahwa siswa harus memiliki lima keterampilan matematika, ialah: 1) Uraian Konseptual; 2) Kelancaran Prosedural; 3) Kompetensi Strategis; 4) Penalaran Adaptif; 5) Disposisi Produktif. Kilpatrick et al., (2001) menyatakan bahwa kelima keterampilan matematika ini akan membantu memajukan perkembangan ilmu-ilmu lain, dan jika benar-benar menguasai dan mengaplikasikannya, siswa akan merasakan manfaatnya. Salah satu keberhasilan tersebut adalah hal ini dapat dilihat pada kemampuan siswa dalam memecahkan masalah matematika.

Kemampuan menyelesaikan soal matematika siswa dapat dilihat melalui kemampuan kompetensi strategis siswa. Kompetensi strategis adalah komponen inti dari keterampilan matematis (Kilpatrick et al., 2001). Karena kelima komponen keterampilan matematika tersebut saling terikat serta tidak dapat dipisahkan dalam perkembangan kemampuan matematika siswa (Muna et al., 2018). Kemampuan strategis ialah salah satu keterampilan yang harus dipunyai serta ditumbuh kembangkan siswa dalam pembelajaran matematika, karena kemampuan menyelesaikan masalah matematika ialah aspek yang sangat penting dalam pembelajaran matematika (Angraini, 2018). Strategic competence merupakan suatu keterampilan matematika yang mengacu pada keahlian merumuskan, menyajikan, serta memecahkan permasalahan matematika (Kilpatrick et al., 2001).

Muna et al., (2018) menyatakan bahwa pentingnya strategic competence siswa di Indonesia tidak sesuai dengan tingkatan strategic competence yang ada. Menurut hasil PISA tahun 2012 menunjukkan bahwa siswa Indonesia mendapatkan skor 368 poin disaat perumusan masalah, 369 poin untuk penerapan konsep, serta 379 poin untuk menafsirkan hasil solusi (Himmah H.A., 2017). Hasil ini menunjukkan bahwa strategic competence masih sangat rendah dalam penerapan konsep dan perumusan masalah (Muna et al., 2018). Berdasarkan hasil (OECD, 2015) Indonesia menempati urutan ke-63 dari 70 negara partisipan, dengan skor 386 untuk literasi matematika. Cina menjadi juara pertama dengan 613 poin. Sejak 2002 sampai 2012, Indonesia berada di urutan 38 teratas (OECD, 2015). Kesimpulan yang diambil dari hal ini adalah bahwa siswa Indonesia belum memaksimalkan strategic competencenya dalam menyelesaikan permasalahan kontekstual (Sigit et al., 2018). Wardhani, (2005) mengemukakan bahwa masalah matematika pada PISA lebih fokus pada keahlian penalaran dan pemecahan permasalahan. Hasil PISA menunjukkan bahwa strategic competence siswa Indonesia masih sangat rendah (Amalia, 2016).

Salah satu cara untuk mengembangkan kemampuan strategic competence adalah dengan cara 
menyelesaikan tipe soal matematika Higher-Order Thinking skill. Ermayani et al., (2019) menyatakan bahwa jika siswa dapat belajar tentang masalah dan dapat mangaplikasikan ilmunya dalam situasi baru maka dikatakan mampu memecahkan masalah. Kemampuan ini disebut keterampilan berpikir tingkat tinggi (Ermayani et al., 2019). King dkk, (2007) mengemukakan bahwa higher-order thinking skills didefinisikan sebagai berpikir kritis, reflektif logis, metakognitif, dan kreatif. Pemberian masalah matematika yang bersangkutan dengan higher-order thinking skills dianggap sebagai upaya untuk mengatasi ketergantungan siswa pada rumus-rumus yang digunakan dalam menyelesaikan masalah matematika. Siswa bisa terlatih untuk mengembangkan kreativitas dan pemikiran logis untuk menemukan solusi atas masalah yang diberikan (Wicasari \& Ernaningsih, 2016).

Level berpikir siswa ada enam tingkatan, level berpikir pada C4, C5, dan C6 adalah tingkat berpikir tingkat tinggi (Higher Order Thinking Skills). (Anderson et al., 2001) menyatakan bahwa terdapat beberapa indikator yang dapat mengukur kemampuan tingkat tinggi sesorang, yaitu: 1) Analyze (C4), yaitu kemampuan menganalisis informasi yang masuk agar dapat mengidentifikasi dan membedakan sebab serta akibat dari sebuah scenario yang sulit untuk menentukan atau merumuskan soal; 2) Evaluation (C5), yaitu siswa dapat menggunakan standar yang memenuhi standar yang ada untuk mengevaluasi solusi, ide dan metode untuk memastikan keefektifan/manfaatnya; 3) Create (C6), yaitu siswa dapat merancang pemecahan masalah dan mengatur elemen dan bagian menjadi struktur baru yang belum pernah terjadi sebelumnya.

Keterampilan matematika yang terlibat dalam kemampuan merumuskan, menyajikan, dan memecahkan masalah matematika ialah kompetensi strategis (Kilpatrick et al., 2001). Ostler, (2011) menyatakan bahwa kemampuan strategis adalah kemampuan untuk membentuk model matematika yang cocok dan menentukan strategi yang benar untuk menyelesaikan suatu masalah. Turner, (2010) menyatakan bahwa kompetensi strategis, dengan kata lain, perencanaan strategis untuk menyelesaikan permasalahan matematika melibatkan serangkaian proses pengendalian kontrol yang membimbing individu untuk secara efektif mengidentifikasi, merumuskan, dan memecahkan masalah. Suh, (2007) menyatakan bahwa kompetensi strategis adalah kemampuan siswa untuk merumuskan dan melaksanakan rencana serta memecahkan masalah dengan strategi yang benar. Syukriani, (2016) menyatakan bahwa kompetensi strategis adalah suatu keterampilan yang diperlukan siswa dalam menggunakan strategi yang tepat untuk menyelesaikan permasalahan matematika.

Berdasarkan pernyataan di atas, maka tujuan dari penelitian ini adalah untuk mengetahui dan mengukur kemampuan strategic competence siswa dalam menyelesaikan tipe soal higher-order thinking skills dalam proses pembelajaran matematika terkhusus pada masalah sistem persamaan linear dua variabel. Oleh karena itu, harus dilakukan penelitian mengenai "Kemampuan Strategic Competence Siswa SMP dalam Menyelesaikan Tipe Soal Matematika Higher-Order Thinking Skills". 
Kemampuan Strategic Competence Siswa SMP dalam Menyelesaikan Tipe Soal Matematika Higher Order Thinking Skills, Melliana Christie Nugroho, Tri Nova Hasti Yunianta

\section{METODE}

Metode penelitian yang digunakan pada penelitian merupakan penelitian kualitatif deskriptif. Pemilihan penelitian deskriptif kualitatif didasari oleh tujuan penelitian untuk mengetahui kemampuan strategic competence siswa SMP dalam menyelesaikan tipe soal matematika higher-order thinking skills. Teknik pengumpulan data yang digunakan yaitu triangulasi metode.

Subjek penelitian ini adalah siswa kelas VIII SMP Negeri 3 Salatiga. Penelitian ini dilaksanakan pada hari kamis, 1 April 2021 bertempat di SMP Negeri 3 Salatiga. Subjek penelitian diambil sebanyak 3 dari 12 siswa kelas VIII SMP Negeri 3 Salatiga. Subjek penelitian sudah mempelajari dan mengetahui cara penyelesaian soal sistem persamaan linear dua variabel. Pengambilan subjek dilihat dari hasil pengerjaan soal diambil subjek penelitian tersebut meliputi siswa kemampuan tinggi, siswa kemampuan sedang dan siswa kemampuan rendah. Pemilihan subjek ini bersumber pada pertimbangan guru serta peneliti menurut hasil pekerjaan soal.

Instrumen utama penelitian ini adalah peneliti sendiri dengan bantuan instrumen pendukung berupa tes tertulis dengan salah satu soalnya yaitu, Andi, bardi, dan Caca bersama-sama membeli buku tulis dan pensil yang sejenis. Andi membeli 4 buku tulis dan 1 pensil seharga $R p 16.000$. Bardi membeli 6 buku tulis dan 2 pensil seharga $R p$ 25.000. Jika Caca membeli 4 buku tulis dan 3 pensil, berapa rupiah ia harus membayar?, lalu dilanjutkan dengan wawancara, dan dokumentasi. Asy'ari et al., (2020) data tes tertulis dianalisis secara kualitatif didasarkan pada indikator strategic competence sebagai berikut:

Tabel 1. Indikator Strategic Competence

\begin{tabular}{|l|l|}
\hline \multicolumn{1}{|c|}{ Aspek } & \multicolumn{1}{c|}{ Indikator } \\
\hline Memformulasikan & - $\begin{array}{l}\text { Tulis dan jelaskan informasi yang diketahui dan } \\
\text { diminta }\end{array}$ \\
& $\begin{array}{l}\text { Jelaskan hubungan antara informasi yang diketahui } \\
\text { dari pertanyaan yang diajukan oleh materi yang } \\
\text { dipelajari sebelumnya }\end{array}$ \\
\hline Merepresentasikan & - Merumuskan masalah dalam kalimat matematika \\
\hline Menyelesaikan & - Pilih strategi/metode/konsep sebagai solusi \\
\hline
\end{tabular}

Sumber: https://doi.org/10.33654/math.v6i1.916

\section{HASIL DAN DISKUSI}

Berdasarkan kemampuan strategic competence siswa yang telah dijabarkan sebelumnya, maka kemampuan strategic competence dibagi menjadi tiga bagian yaitu kemampuan strategic competence pada subjek kemampuan berpikir tinggi, sedang dan rendah.

\section{Kemampuan Strategic Competence pada Subjek Kemampuan Tinggi}

Bersumber pada hasil pekerjaan siswa OK nampak bahwa siswa OK sudah memenuhi indikatorindikator kemampuan strategic competence. 


\section{Strategic Competence Subjek dalam Aspek Memformulasikan}

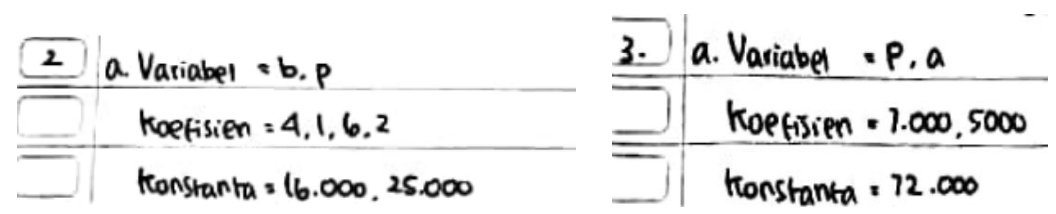

Gambar 1. Hasil Pekerjaan Siswa OK

Berdasarkan Gambar 1, siswa OK mampu menuliskan informasi yang ditemukan dan yang ditanyakan dari soal yang diberikan. Untuk mengetahui lebih dalam strategic competence siswa OK pada aspek memformulasikan soal maka dilakukan wawancara berikut:

$P \quad$ : Bagaimana kamu mengetahui variabel, koefisien dan konstanta pada soal yang diberikan untuk soal nomor 2?

OK : Dari soal bu, untuk soal nomor dua variabelnya saya memisalkan buku tulis dengan $b$ dan memisalkan pensil dengan p, lalu untuk koefisiennya didapat dari 4 buku tulis dan 1 pensil untuk milik Andi lalu 6 buku tulis dan 2 pensil untuk milik Bardi, selanjutnya untuk konstantanya itu dari jumlah harga beli buku tulis dan pensil milik Andi sebesar Rp 16.000 dan milik Bardi sebesar Rp 25.000

$P \quad$ : Lalu bagaimana dengan variabel, koefisien dan konstanta untuk nomor tiga?

OK : Untuk nomor 3 variabelnya saya memisalkan apel fuji dengan a dan pear madu dengan p kemudian untuk koefisiennya didapat dari harga perbuah apel fuji yaitu Rp 5.000 dan harga perbuah pear madu yaitu Rp 7.000 untuk konstantanya itu dari jumlah semua pembelian apel fuji dan pear madu yaitu $R p 72.000$

$P \quad$ : Apakah ada hubungan soal dengan materi yang pernah di pelajari?

OK : Ada, sistem persamaan linear dua variabel sudah pernah dipelajari dimana sistem persamaan linear dua variabel itu adalah variabel yang pangkat atau derajat sama dengan satu.

Berdasarkan wawancara di atas bahwa siswa OK mampu menentukan variabel, koefisien dan konstanta yang terdapat dalam soal serta mampu menjelaskan keterkaitan soal dengan materi yang pernah dipelajari sebelumnya.

\section{Strategic Competence Subjek dalam Aspek Merepresentasikan}

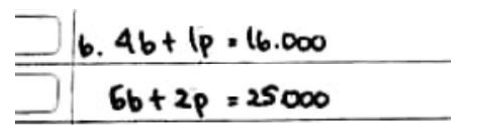

\section{b. $7000 p+5000 a=72.000$}

Gambar 2. Hasil Pekerjaan Siswa OK

Berdasarkan Gambar 2 siswa OK mampu merumuskan soal dengan memisalkan banyaknya buku dan pensil dengan benar, kemudian dapat menuliskan ke dalam model matematika dengan benar pula. Selain itu untuk melihat strategi seperti yang akan digunakan pada aspek memformulasikan soal maka peneliti melakukan wawancara berikut: 
Kemampuan Strategic Competence Siswa SMP dalam Menyelesaikan Tipe Soal Matematika Higher Order Thinking Skills, Melliana Christie Nugroho, Tri Nova Hasti Yunianta

$P \quad$ : Jelaskan strategi atau cara apa yang menurutmu efektif untuk merumuskan soal?

OK : Jadi, saya memisalkan banyaknya buku tulis dan pensil serta memisalkan apel fuji dan pear madu kemudian saya membuat persamaannya.

Berdasarkan wawancara di atas, siswa OK menentukan strategi yang menurutnya efisien dalam merumuskan soal yakni memisalkan banyaknya jumlah buku dan pensil serta apel fuji dan pear madu, kemudian dibuat ke dalam model matematika.

\section{Strategic Competence Subjek dalam Aspek Menyelesaikan}

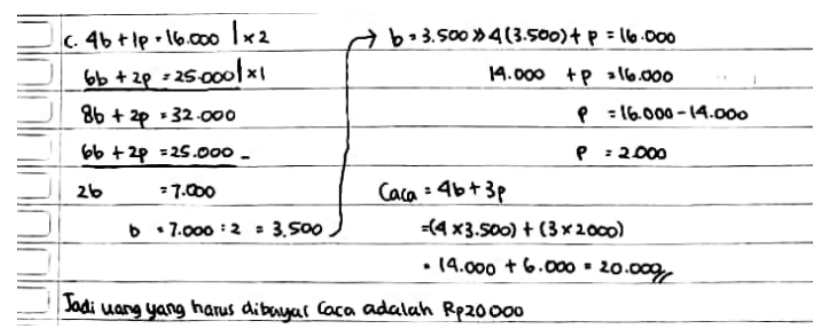

Gambar 3. Hasil Pekerjaan Siswa OK

Berdasarkan Gambar 3 siswa OK menuliskan penyelesian dan menuliskan pemecahan masalah dengan menggunakan model matematika, persamaan dan kata-kata. Untuk mengetahui lebih dalam strategic competence siswa OK pada aspek menyelesaikan saya melakukan wawancara sebagai berikut:

$P \quad$ : Jelaskanlah langkah-langkah penyelesaian yang kamu gunakan untuk soal nomor dua!

OK : Saya memisalkan buku tulis dengan b dan memisalkan pensil dengan p terlebih dahulu, kemudian model matematikanya yaitu $4 b+1 p=16.000$ dan $6 b+2 p=25.000$, lalu dari persamaan tersebut saya menyamakan nilai dengan mengalikan 2 persamaan $4 b+$ $1 p=16.000$ lalu setelah itu saya eliminasi persamaan $4 b+1 p=16.000$ dengan persamaan $6 b+2 p=25.000$ sehingga menghasilkan $b=3.500$ setelah $b$ ketemu kemudian dengan persamaan $4 b+1 p=16.000$ saya substitusikan nilai $b$ sehingga menghasilkan nilai $p=2.000$, lalu yang ditanyakan berapa rupiah yang harus dibayar Caca jika membeli 4 buku tulis dan 2 pensil jadi $4 \times 3500+3 \times 2000$ menghasilkan $14.000+6000=20.000$, jadi Caca harus membayar Rp 20.000 untuk 4 buku tulis dan 3 pensil.

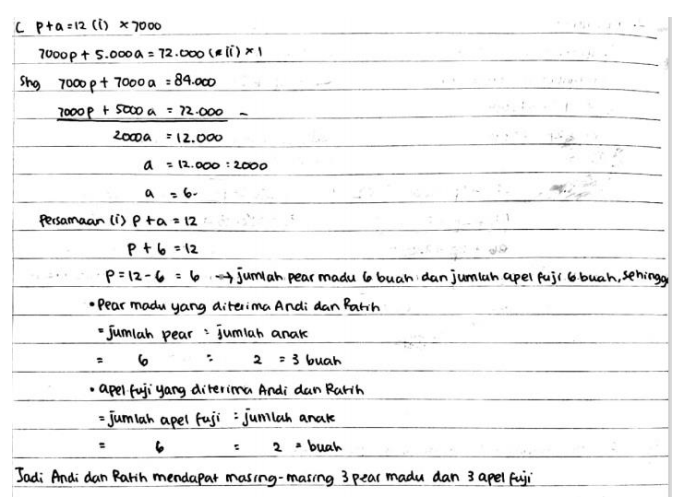

Gambar 4. Hasil Pekerjaan Siswa OK 
Berdasarkan Gambar 4 siswa OK menuliskan penyelesian dan menuliskan pemecahan masalah dengan menggunakan model matematika, persamaan dan kata-kata. Untuk mengetahui lebih dalam strategic competence siswa OK pada aspek menyelesaikan saya melakukan wawancara sebagai berikut:

$P \quad$ : Jelaskanlah langkah-langkah penyelesaian yang kamu gunakan untuk soal nomor tiga!

OK : Saya memisalkan apel fuji dengan a dan memisalkan pear madu dengan $p$ terlebih dahulu, kemudian model matematikanya yaitu $p+a=12$ dan $7000 p+5000 a=$ 72.000, lalu dari persamaan tersebut saya menyamakan nilai $p$ dengan mengalikan 7000 persamaan $p+a=12$ sehinga menjadi $7000 p+7000 a=84.000$ lalu setelah itu saya eliminasi persamaan $7000 p+7000 a=84.000$ dengan persamaan $7000 p+5000 a=72.000$ sehingga menghasilkan $a=6$ buah apel setelah aketemu kemudian dengan persamaan $p+a=12$ saya substitusikan nilai a sehingga menghasilkan nilai $p=6$ buah pear, lalu yang ditanyakan berapa buah apel fuji dan pear madu yang didapat oleh Andi dan Ratih? Maka buah yang apel fuji dan pear madu yang didapat Andi dan Ratih adalah masing-masing 3 buah.

Berdasarkan wawancara siswa OK menyelesaikan soal sesuai dengan strategi yang benar dan memperoleh hasil yang benar dari soal, dikarenakan OK merupakan siswa yang memiliki kemampuan strategic competence dengan kategori tinggi.

\section{Kemampuan Strategic Competence pada Subjek Kemampuan Sedang}

Bersumber dari hasil pekerjaan siswa MH nampak bahwa siswa MH sudah memenuhi beberapa indikator-indikator kemampuan strategic competence.

\section{Strategic Competence Subjek dalam Aspek Memformulasikan}

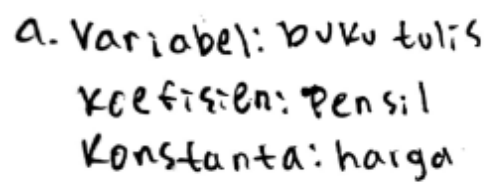

\section{Gambar 5. Hasil Pekerjaan Siswa MH}

Berdasarkan Gambar 5, siswa MH mampu menuliskan informasi yang diketahui dan yang ditanyakan dari soal. Untuk mengetahui lebih dalam strategic competence siswa MH pada aspek memformulasikan soal maka peneliti melakukan wawancara berikut:

$P \quad: \quad$ Bagaimana kamu mengetahui variabel, koefisien dan konstanta pada soal yang diberikan?

MH : Emm, saya masih sedikit bingung bu untuk menentukan variabel, koefisien dan konstantanya.

$P \quad: \quad$ Apakah ada hubungan soal dengan materi yang pernah kamu pelajari?

MH : Ada, sistem persamaan linear dua variabel sudah pernah dipelajari di semester satu. 
Kemampuan Strategic Competence Siswa SMP dalam Menyelesaikan Tipe Soal Matematika Higher Order Thinking Skills, Melliana Christie Nugroho, Tri Nova Hasti Yunianta

Berdasarkan wawancara di atas, siswa MH masih bingung dalam menetapkan variabel, koefisien dan konstanta yang terdapat pada soal dan mampu menjawab keterkaitan soal dengan materi yang pernah dipelajari sebelumnya.

Strategic Competence Subjek dalam Aspek Merepresentasikan
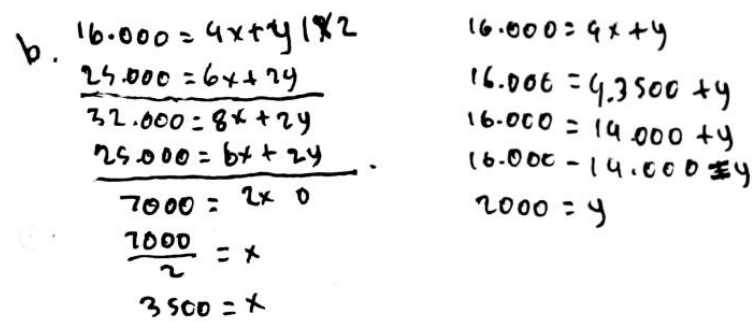

Gambar 6. Hasil Pekerjaan Siswa MH

Siswa MH mampu merepresentasikan model matematika ke dalam bentuk persamaan sistem persamaan linear dua variabel. Dapat dilihat pada Gambar 6, meskipun hasil pekerjaan MH tidak sesuai seperti yang diminta oleh soal yang mana soal hanya meminta menuliskan persamaannya saja dari soal yang telah diberikan. Selain itu untuk mengetahui strategi yang akan digunakan pada aspek memformulasikan soal maka peneliti melakukan wawancara berikut:

$P \quad$ : Jelaskan strategi atau cara apa yang menurutmu efektif untuk merumuskan soal?

MH : Jadi, saya menuliskan persamaan dari soal bu, lalu saya menggunakan cara eliminasi dan substitusi.

Berdasarkan wawancara di atas, siswa MH mengetahui strategi yang menurutnya efisien dalam merumuskan soal, siswa MH mampu menuliskan persamaan yang terdapat di soal namun masih bingung dalam menentukan variabel, koefisien, dan konstanta yang ada di soal. Siswa MH juga tidak memahami betul pertanyaan yang ada di soal dimana seharusnya soal poin $b$ hanya dituliskan persamaan saja, namun siswa MH menyelesaikan soal sekaligus di soal poin $b$.

Strategic Competence Subjek dalam Aspek Menyelesaikan

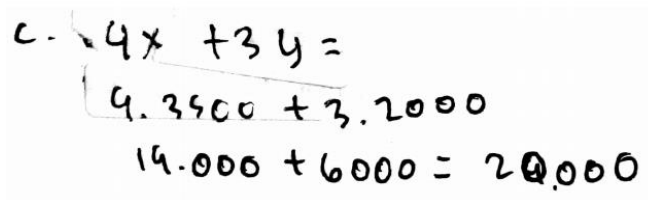

Gambar 7. Hasil Pekerjaan Siswa MH

Siswa MH mampu menyelesaikan permasalahan soal yang diberikan hanya tidak dapat menyelesaikan soal no 3. Siswa MH mengetahui bahwa dengan mengeliminasi dan mensubstitusi persamaan pada soal yang dibarikan akan memperoleh hasil penyelesaiannya. Jawaban siswa MH benar namun harusnya penyelesaian menyeluruh berada di soal poin $c$ sedangkan siswa $\mathrm{MH}$ menulis penyelesaian menyeluruh di poin $b$ yang seharusnya hanya ditulis persamaannya saja, dikarenakan siswa $\mathrm{MH}$ merupakan siswa yang memiliki kemampuan strategic competence dengan kategori sedang. 


\section{Kemampuan Strategic Competence pada Subjek Kemampuan Rendah}

Bersumber dari hasil pekerjaan MD nampak bahwa siswa MD belum memenuhi indikator-indikator kemampuan strategic competence.

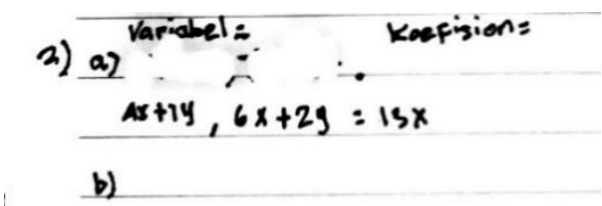

c) $R_{p} 20.000$

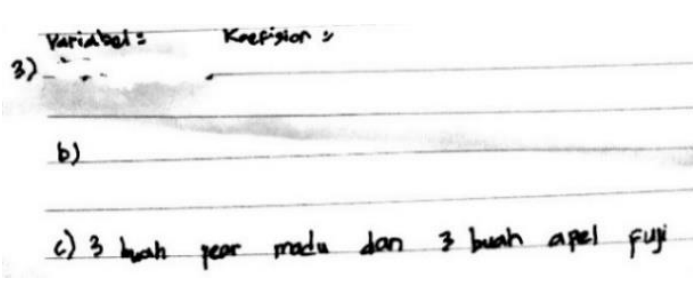

Gambar 8. Hasil Pekerjaan Siswa MD

\section{Strategic Competence Subjek dalam Aspek Memformulasikan}

Berdasarkan Gambar 8, siswa MD tidak dapat menuliskan informasi yang diketahui dan yang ditanyakan dari soal yang diberikan. Untuk mengetahui lebih dalam strategic competence siswa MD pada aspek memformulasikan maka peneliti melakukan wawancara berikut:

$P \quad:$ Bagaimana kamu mengetahui variabel, koefisien dan konstanta pada soal yang diberikan?

$M D$ : Emm, saya tidak tahu bu

$P \quad$ : Kamu ingat atau tahu apa itu variabel, koefisien, dan konstanta?

$M D$ : Hehe, tidak bu, saya lupa.

$P \quad$ : Apakah ada hubungan soal dengan materi yang pernah kamu pelajari?

$M D$ : Emm, iya bu SPLDV, pernah dipelajari tapi saya lupa.

Berdasarkan wawancara di atas, siswa MD lupa atau tidak dapat menentukan variabel, koefisien dan konstanta yang terdapat pada soal dan tidak dapat menjelaskan keterkaitan soal yang ada.

\section{Strategic Competence Subjek dalam Aspek Merepresentasikan}

Siswa MD belum mampu merepresentasikan model matematika yang telah ia peroleh dalam bentuk persamaan SPLDV dapat dilihat pada Gambar 7. Selain itu untuk mengetahui strategi yang akan digunakan pada aspek memformulasikan soal maka peneliti melakukan wawancara berikut:

$P \quad$ : Jelaskan strategi atau cara apa yang menurutmu efektif untuk merumuskan soal?

MD : Emm, saya tidak tahu buk, lupa hehe.

$P \quad: \quad$ Kamu sudah pernah mempelajari materi sistem persamaan linear dua variabel?

MD : Iya, sudah bu tapi saya lupa bagaimana caranya.

Berdasarkan wawancara di atas, siswa MD tidak mengetahui strategi yang menurutnya efektif dalam merumuskan soal, siswa MD juga tidak mampu menuliskan persamaan yang terdapat di soal serta tidak dapat menentukan variabel, koefisien, dan konstanta yang ada di soal.

\section{Strategic Competence Subjek dalam Aspek Menyelesaikan}

Siswa MD tidak mampu menyelesaikan permasalahan soal yang diberikan. Siswa MD tidak mengetahui strategi dan penyelesaian seperti apa agar memperoleh hasil. Jawaban siswa MD sebenarnya 
Kemampuan Strategic Competence Siswa SMP dalam Menyelesaikan Tipe Soal Matematika Higher Order Thinking Skills, Melliana Christie Nugroho, Tri Nova Hasti Yunianta

benar namun seharusnya penyelesaian menggunakan strategi dan cara yang sebelumnya sudah pernah dipelajari, hanya saja siswa MD lupa atau tidak dapat menyelesaikannya, dikarenakan siswa MD merupakan siswa yang memiliki kemampuan strategic competence dengan kategori rendah. Berdasarkan pemecahan masalah dan wawancara pada ketiga subjek, penyelesaian soal matematika pada setiap soal untuk setiap subjek dapat dilihat pada Tabel 2.

Tabel 2. Penyelesaian Soal Matematika Oleh 3 Subjek

\begin{tabular}{|c|c|c|c|}
\hline \multirow{2}{*}{ Aspek } & \multicolumn{3}{|c|}{ Subjek } \\
\hline & OK & MH & MD \\
\hline Memformulasikan & $\begin{array}{l}\text { Mampu } \\
\text { memformulasikan } \\
\text { permasalahan dengan } \\
\text { menuliskan variabel, } \\
\text { konstantar dan } \\
\text { koefisien dalam soal } \\
\text { menjadi model } \\
\text { matematika. }\end{array}$ & $\begin{array}{lr}\text { (-) Kurang mampu } \\
\text { memformulasikan } \\
\text { permasalahan dengan } \\
\text { menuliskan variabel, } \\
\text { konstanta } & \text { dan } \\
\text { koefisien dalam soal } \\
\text { menjadi } & \text { model } \\
\text { matematika } & \\
(+) \text { Paham yang } \\
\text { dimaksud dalam } \\
\text { pertanyaan di soal. }\end{array}$ & $\begin{array}{l}\text { Tidak mampu } \\
\text { memformulasikan } \\
\text { permasalahan dengan } \\
\text { menuliskan variabel, } \\
\text { konstanta dan } \\
\text { koefisien dalam soal } \\
\text { menjadi }\end{array}$ \\
\hline Merepresentasikan & $\begin{array}{l}\text { Mampu } \\
\text { mempresentasikan } \\
\text { variabel, konstanta, } \\
\text { dan koefisien ke } \\
\text { dalam persamaan } \\
\text { spldv. }\end{array}$ & $\begin{array}{l}\text { Kurang mampu } \\
\text { mempresentasikan } \\
\text { variabel, konstanta, } \\
\text { dan koefisien ke } \\
\text { dalam persamaan } \\
\text { spldv. }\end{array}$ & $\begin{array}{l}\text { Tidak mampu } \\
\text { mempresentasikan } \\
\text { variabel, konstanta, } \\
\text { dan koefisien ke } \\
\text { dalam persamaan } \\
\text { spldv. }\end{array}$ \\
\hline Menyelesaikan & $\begin{array}{l}\text { Mampu } \\
\text { menyelesaikan } \\
\text { masalah } \\
\text { memberikan } \\
\text { kesimpulan. }\end{array}$ & $\begin{array}{l}\text { Mampu } \\
\text { menyelesaikan } \\
\text { masalah namun tidak } \\
\text { dapat memberikan } \\
\text { kesimpulan. }\end{array}$ & $\begin{array}{l}\text { Tidak mampu } \\
\text { menyelesaikan } \\
\text { masalah dan } \\
\text { memberikan } \\
\text { kesimpulan }\end{array}$ \\
\hline
\end{tabular}

Dilihat dari hasil tes serta hasil wawancara yang ditemukan bahwa kemampuan strategic competence siswa SMP masih terbilang rendah. Hal ini sejalan dengan (Amalia, 2016) bahwa hasil PISA menunjukkan bahwa strategic competence siswa Indonesia masih sangat rendah. Siswa dengan kemampuan berpikir tinggi lebih sanggup memenuhi aspek kemampuan strategic competence, untuk siswa dengan kemampuan berpikir sedang hanya sanggup memenuhi beberapa aspek kemampuan strategic competence, sedangkan untuk siswa dengan kemampuan berpikir rendah belum sanggup memenuhi kemampuan strategic competence.

Siswa dengan kemampuan berpikir tinggi mampu menganalisis atau memformulasikan suatu soal cerita ke dalam model matematika dan mengubahnya ke bentuk persamaan serta dapat menyelesaikan permasalahan dalam soal dengan metode sistem persamaan linear dua variabel yaitu eliminasi dan substitusi. Siswa dengan kemampuan berpikir sedang sebenarnya mampu mengerti pertanyaan dalam soal hanya saja tidak bisa menentukan variabel, koefisien dan konstanta ke dalam model matematika, namun dapat menyelesaikan soal dengan cara eliminasi dan substitusi. Syukriani, (2016) menyatakan bahwa 
menggunakan strategi dalam memahami, memformulasikan dan merepresentasikan suatu masalah amat dipengaruhi oleh keahlian belajar siswa.

Hal ini menunjukkan bahwa ketika membaca sebuah pertanyaan, siswa akan langsung memikirkan isi dari pertanyaan yang sedang dibacanya. Setelah membaca soal, siswa segera mengonversi imajinasinya menjadi model matematika pada lembar jawaban. Kilpatrick et al., (2001) menyatakan bahwa untuk merepresentasikan suatu masalah dengan benar, perlu dipahami masalah tersebut dan membentuk gambaran psikologis. Sesungguhnya siswa dapat memahami masalah dengan baik, namun siswa tidak akan mengungkapkan pemahamannya secara tertulis (Melanie et al., 2019).

Siswa dengan kemampuan berpikir rendah tidak dapat merumuskan atau menganalisis masalah yang diberikan, atau bahkan menggunakan metode eliminasi dan substitusi sebagai alternatif penyelesaiannya. Hal ini dikarenakan siswa tidak mampu menyajikan masalah yang diberikan. Penelitian yang dilakukan Syafik, (2009) juga membuktikan hal tersebut. Penelitian tersebut menunjukkan bahwa siswa mengalami kesulitan memecahkan masalah cerita. Salah satu penyebabnya ialah rendahnya kemampuan siswa dalam menerjemahkan kalimat sehari-hari ke dalam kalimat matematika.

Hal ini sesuai dengan pandangan Kilpatrick et al., (2001) bahwa siswa harus memiliki kemampuan matematika yang penting yaitu kemampuan strategic competence yang meliputi kemampuan merumuskan, menyajikan, dan memecahkan masalah matematika. Jika siswa tidak dapat merumuskan atau menyajikan masalah yang mereka hadapi, mereka akan kesulitan untuk menyelesaikannya. Turner, (2010) menyatakan bahwa pemecahan masalah matematika melibatkan serangkaian proses pengendalian kontrol yang dapat membimbing individu untuk secara efektif mengidentifikasi, merumuskan dan memecahkan masalah. Karakteristik keterampilan ini dicirikan dengan penggunaan strategi untuk memecahkan suatu masalah yang disebabkan oleh tugas ataupun situasi serta untuk memandu pelaksanaanya (Yulianti et al., 2017).

\section{KESIMPULAN}

Menjawab rumusan masalah pada penelitian kemampuan strategic competence untuk tipe soal higher-order thinking skills siswa SMP dalam menyelesaikan masalah matematika sistem persamaan linaer dua variabel, ditemukan kesimpulan bahwa tingkat kemampuan siswa berbeda-beda. Siswa dengan kemampuan berpikir tinggi dapat mencapai ketiga indikator strategic competence, untuk siswa dengan kemampuan berpikir sedang hanya dapat mencapai dua indikator saja, sedangkan untuk siswa dengan kemampuan berpikir rendah tidak mampu memenuhi indikator yang ada. Oleh karena itu, guru perlu membantu siswa dalam menumbuhkan kemampuan strategic competence.

\section{UCAPAN TERIMA KASIH}

Peneliti mengucapkan terima kasih kepada kepala sekolah dan guru di SMP Negeri 3 Salatiga yang telah memberi izin kepada penulis untuk mengambil data di sekolah tersebut. Terimakasih yang sebesarbesarnya kepada orang tua yang selalu senantiasa memberikan semangat kepada peneliti. Terimakasih kepada dosen pembimbing yang telah memberikan bimbingan dalam menyelesaikan artikel ini. 
Kemampuan Strategic Competence Siswa SMP dalam Menyelesaikan Tipe Soal Matematika Higher Order Thinking Skills,

Terimakasih kepada bapak dan ibu dosen yang telah memberi ilmu dan pengajaran yang sangat bermanfaat kepada peneliti sehingga peneliti dapat menyelesaikan tugas-tugas hingga artikel ini.

\section{REFERENSI}

Afrilianto, M. (2012). Peningkatan Pemahaman Konsep Dan Kompetensi Strategis Matematis Siswa Smp Dengan Pendekatan Metaphorical Thinking. Infinity Journal, $1(2), \quad 192$. https://doi.org/10.22460/infinity.v1i2.19

Amalia, K. (2016). Peningkatan Kompetensi Strategis Matematis Siswa Sekolah Menengah Kejuruan (Smk) Melalui Strategi Team-Based Learning. Infinity Journal, 5(1), 1. https://doi.org/10.22460/infinity.v5i1.p1-14

Anderson, L. W., Krathwohl, D. R., \& Bloom, B. S. (2001). A taxonomy for learning, teaching, and assessing: a revision of Bloom's taxonomy of educational objectives. 41(4), 352.

Angraini, M. E. (2018). ANALISIS KOMPETENSI STRATEGIS MATEMATIS SISWA DENGAN GAYA BELAJAR ASSIMILATOR PADA PEMECAHAN MASALAH MATEMATIKA DI KELAS VIII SMP. 1 10.

Asy’ari, M. F., Siswono, T. Y., \& Lukito, A. (2020). Kompetensi Strategis Siswa dalam Menyelesaikan Persoalan Program Linear Ditinjau dari Kecemasan Matematika. Math Didactic: Jurnal Pendidikan Matematika, 6(1), 98-109.

Darmawan, I., Kharismawati, A., Hendriana, H., \& Purwasih, R. (2018). Analisis Kesalahan Siswa SMP Berdasarkan Newman dalam Menyelesaikan Soal Kemampuan Berpikir Kritis Matematis pada Materi Bangun Ruang Sisi Datar. JURING (Journal for Research in Mathematics Learning), 1(1), 71. https://doi.org/10.24014/juring.v1i1.4912

Ermayani, L., Suarjana, I. M., \& Parmiti, D. P. (2019). Analisis Kemampuan Siswa dalam Menyelesaikan Soal Pecahan Sederhana. Jurnal Pedagogi Dan Pembelajaran, 1(1), 9. https://doi.org/10.23887/jp2.v1i1.19325

Kilpatrick, J., Swafford, J., \& Findell, B. (2001). Helping Children Learn Mathematics. In Helping Children Learn Mathematics. https://doi.org/10.17226/10434

Melanie, M. E., Hartoyo, A., \& Ahmad, D. (2019). Deskripsi Proses Penyelesaian Soal Cerita Materi Perbandingan Pada Siswa Kelas VII SMP. Journal of Chemical Information and Modeling, 53(9), 1689-1699.

Muna, T., Islam, U., Sunan, N., Surabaya, A., Tarbiyah, F., Keguruan, D. A. N., Pendidikan, J., Dan, M., Studi, P., \& Matematika, P. (2018). Tatimmatul Muna_D94214112.

National Research Council. (2001). Adding it up: Helping children learn mathematics. Book Reviews, 34(6). OECD. (2015). Pisa 2015 Results in Focus. https://doi.org/10.1596/28293

Ostler, E. (2011). Teachiing Adaptive and Strategic Reasoning Through Formula Derivation: Beyond Formal Semiotics. International Journal of Mathematics Science Education, 4(2), 16-26.

Rifatul Himmah H.A., N. (2017). Profil Pemecahan Masalah Matematika Model Pisa Berdasarkan 
Kemampuan Matematika Siswa Sma. MATHEdunesa, 5(3).

Sariningsih, R., \& Purwasih, R. (2017). Pembelajaran Problem Based Learning Untuk Meningkatkan Kemampuan Pemecahan Masalah Matematis Dan Self Efficacy Mahasiswa Calon Guru. JNPM (Jurnal Nasional Pendidikan Matematika), 1(1), 163. https://doi.org/10.33603/jnpm.v1i1.275

Sigit, J., Utami, C., \& Prihatiningtyas, N. C. (2018). Analisis Kompetensi Strategis Matematis Siswa pada Sistem Persamaan Linier Tiga Variabel (SPLTV) Kelas X SMK Negeri 3 Singkawang. Variabel, 1(2), 60. https://doi.org/10.26737/var.v1i2.811

Suh, J. M. (2007). Tying It All Together Mathematical Proficiency for All Students. Teaching Children Mathematics, 163-169.

Syukriani, A. (2016). Kompetensi strategis siswa sma berkemampuan matematika tinggi dalam menyelesaikan masalah matematika. Prosiding Seminar Nasional, 2(1), 83-91.

Turner, R. (2010). Identifying Cognitive Processes Important to Mathematics Learning but Often Overlooked. Australian Mathematics Teacher, 67(2), 22-26.

Wicasari, B., \& Ernaningsih, Z. (2016). Analisis Kemampuan Berpikir Siswa dalam Menyelesaikan Permasalahan Matematika yang Berorientasi pada HOTS. Prosiding Seminar Nasional Reforming Pedagogy, 249-254.

Yulianti, Hartoyo, A., \& BS, D. A. (2017). Kompetensi Strategis Siswa Dalam Menyelesaikan Soal Cerita pada Materi Program Linier di SMK-SMTI Pontianak. Jurnal Pendidikan Dan Pembelajaran Khatulistiwa, 6(8), 1-8. 